\title{
ANALISIS PENGARUH SUKU BUNGA SBI, UANG BEREDAR, INFLASI DAN NILAI TUKAR TERHADAP INDEKS HARGA SAHAM JAKARTA ISLAMIC INDEX (JII) PERIODE 2009-2014
}

\author{
Hafidz Ash-Shidiq ${ }^{1}$, Aziz Budi Setiawan² \\ 1 Program Studi Perbankan Syariah, Sekolah Tinggi Ekonomi Islam SEBI, \\ Depok, Jawa Barat. \\ 2Program Studi Perbankan Syariah, Sekolah Tinggi Ekonomi Islam SEBI, \\ Depok, Jawa Barat. Email: setiawan.aziz@gmail.com
}

\begin{abstract}
ABSTRAK: Penelitian ini bertujuan untuk menganalisis pengaruh antara suku bunga SBI, jumlah uang beredar (m2), inflasi dan nilai tukar rupiah IDR/USD terhadap Jakarta Islamic Index di Bursa Efek Indonesia, dengan periode pengamatan selama Januari 2009 - Desember 2014. Data yang digunakan dalam penelitian ini merupakan data yang terdiri dari data bulana. Metode analisis yang digunakan adalah analisis regresi berganda. Pengolahan data tersebut dilakukan dengan menggunakan Eviews 7. Hasil penelitian menunjukkan bahwa secara parsial suku bunga SBI, jumlah uang beredar (m2), dan inflasi tidak berpengaruh signifikan terhadap JII. Sedangkan nilai tukar rupiah mempunyai pengaruh negatif signifikan terhadap JII. Hasil uji koefisien determinasi menunjukkan bahwa nilai Adjusted R-Square 33,37\%. Secara simultan perubahan variabel suku bunga SBI, jumlah uang beredar (m2), inflasi dan nilai tukar rupiah berpengaruh positif signifikan terhadap Jakarta Islamic Indek (JII).
\end{abstract}

Kata Kunci: Jakarta Islamic Indek (JII), Inflasi, suku bunga SBI, nilai tukar rupiah IDR/USD, jumlah uang beredar (m2)

\begin{abstract}
The purpose of this research was to analyze the influence of interest rate of SBI, money supply ( $\mathrm{m} 2)$, inflation and rupiah exchange rate on the Jakarta Islamic Index in Indonesia Stock Exchange, with the observation period during January 2009 - Desember 2014. The data used in this study is a quantitative secondary data consisting of monthly data. The analysis method used is multiple linear regression analysis, clasical assumption test, and determination coefficient test. Data processing was performed using Eviews 7. The result showed that partially interest rate of SBI, money supply (m2), and inflation not influenced significant to the JII. Meanwhile, rupiah exchange rate have a negative effect and significant to the JII. The test results showed that the value of the coefficient of determination Adjusted $R$ Square 33,37\%. Simultaneously variables interest rate of SBI, money supply (m2), inflation and rupiah exchange rate movement have a positive significant effect to the Jakarta Islamic Index (JII).
\end{abstract}

Keywords: Jakarta Islamic Index, Inflation, interest rate of (SBI), Exchange rate, nad Money suply (M2)

\section{PENDAHULUAN}

Hadirnya pasar modal syariah telah memainkan peran penting dalam mengubah topografi sistem keuangan dunia. Industri keuangan syariah mengalami perkembangan 
pesat pada beberapa dekade terakhir. Saat ini pasar modal syariah bukan lagi menjadi tren dikalangan negara muslim semata, perkembangan industri keuangan syariah yang mencapai $15 \%$ pertahun diseluruh dunia menjadikan negara-negara kapitalis dan liberal sekalipun tertarik membuka layanan pasar modal ini. Dalam konsep pertumbuhan ekonomi, pasar modal merupakan salah satu indikator pertumbuhan ekonomi dan tonggak perekonomian sebuah negara. Pasar modal memiliki peran penting sebagai sarana investasi yang berguna bagi pembangunan. Selain itu dalam berinvestasi di pasar modal, nilai harga saham menjadi pertimbangan yang sangat penting (Antonio, Hafidhoh \& Fauzi, 2013).

Langkah awal perkembangan transaksi saham syariah pada pasar modal Indonesia tercatat dengan hadirnya Indeks Syariah atau Jakarta Islamic Index (JII) pada bulan Juli tahun 2000 (Rusbariandi, 2012). Jakarta Islamic Index (JII) merupakan salah satu indeks saham yang ada di Indonesia yang menghitung harga rata-rata untuk jenis saham yang memenuhi kriteria syariah yang tercantum dalam Dewan Pengawas Syariah dan peraturan Bapepam dan LK no IXA.A.13 (Wisambudi, Sudjana \& Topowijono, 2014) dan saham syariah yang menjadi konstituen JII terdiri dari 30 saham yang merupakan sahamsaham syariah paling likuid dan memiliki kapitalisasi pasar yang besar (Wulanditya, Salman \& farid, 2012). JII menjadi jawaban atas keinginan investor yang ingin berinvestasi sesuai syariah. Dengan kata lain, JII menjadi pemandu bagi investor yang ingin menanamkan dananya secara syariah tanpa takut tercampur dengan dana ribawi. Selain itu, JII menjadi tolak ukur kinerja (Benchmark) dalam memilih portofolio saham yang halal (Rahmi \& Irfan, 2012).

Keberadaan kelompok saham-saham syariah dalam Jakarta Islamic Index (JII) relatif masih baru, tetapi dari tahun ke tahun index saham syariah dalam kelompok Jakarta Islamic Index (JII) menunjukkan nilai yang terus naik. Investor memiliki minat yang tinggi terhadap saham syariah. Jika dibandingkan dengan tahun 2009, nilai kapitalisasi saham syariah di JII tercatat sebesar 937.919,08 dan terus mengalami peningkatan di tahun tahun berikutnya. Di tahun 2013 jumlah kapitalisasi JII sebesar $1.672 .099,91$ triliun dan mengalami peningkatan sebesar 272.431,79 triliun atau sebesar $16,29 \%$ di tahun 2014 yaitu sebesar 1.944.531,70 triliun. Sebagai gambaran nilai index saham syariah dalam Jakarta Islamic Index (JII) untuk tahun 2009 hingga tahun 2014 nampak seperti dalam tabel 1.1 berikut :

Tabel 1. 1Kinerja Index Saham Syariah Dalam JII (Tahunan) Tahun 2009-2014

\begin{tabular}{|c|c|c|}
\hline No & Tahun & Indeks JII \\
\hline 1 & 2009 & 417.182 \\
\hline 2 & 2010 & 532.901 \\
\hline 3 & 2011 & 537.031 \\
\hline 4 & 2012 & 594.789 \\
\hline 5 & 2013 & 585.110 \\
\hline 6 & 2014 & 691.039 \\
\hline
\end{tabular}

Sumber : $\underline{w w w . i d x . c o . i d}$

Disamping hal tersebut di atas, pertumbuhan kapitalisasi dan jumlah saham syariah dalam kelompok Jakarta Islamic Index (JII) juga menunjukkan peningkatan yang terus naik. Hal itu terlihat dari tabel 1.2 dibawah ini. 
Tabel 1. 2 Perkembangan Kapitalisasi dan Jumlah Saham Syariah tahun 2009 - 2014

\begin{tabular}{|c|c|c|c|}
\hline Tahun & Periode & Jmlh Saham Syariah & Kapitalisasi JII \\
\hline 2009 & I & 198 & $937.919,08$ \\
\hline & II & 199 & \\
\hline 2010 & 1 & 210 & $1.134 .632,00$ \\
\hline & II & 228 & $1.414 .983,81$ \\
\hline 2011 & I & 234 & \\
\hline & II & 253 & $1.671 .004,23$ \\
\hline 2012 & I & 304 & $1.672 .099,91$ \\
\hline & II & 321 & \\
\hline 2013 & I & 310 & $1.944 .531,70$ \\
\hline & II & 336 & \\
\hline 2014 & I & 322 & \\
\hline & II & 334 & \\
\hline
\end{tabular}

Sumber : Otoritas Jasa Keuangan 2014 (OJK)( data diolah).

Berdasarkan dari dua tabel di atas, mengindikasikan bahwa keberadaan saham syariah sangat diminati oleh para investor, hal itu tergambar dari semakin meningkatnya index saham syariah dalam hal ini JII meskipun di tahun 2013 mengalami penurunan akan tetapi di tahun 2014 indek saham kembali mengalami peningkatan serta peningkatan jumlah saham syariah tiap tahunnya, meskipun beberapa kali mengalami fluktuasi. Akan tetapi selalu mengalami kenaikan dari periode sebelumnya dalam setahun. Sedangkan nilai kapitalisasi saham syariah yang ditunjukkan oleh Jakarta Islamic Index (JII) selalu mengalami trend peningkatan dari tahun-tahun sebelumnya. Akan tetapi jika melihat dari pertumbuhan harga indeks saham antara JII, LQ45 dan IHSG maka pertumbuhan masing masing indek selalu berfluktuasi dimana pada tahun 2009 JII mengalami pertumbuhan tertinggi sedangkan di tahun-tahun berikutnya pertumbuhan JII cenderung lebih kecil dibandingkan dengan pertumbuhan indek lainnya. Hal ini tergambar dalam tabel 1.3 berikut ini

Tabel 1. 3 Pertumbuhan Harga Indek JII, LQ 45 dan IHSG 2009 - 2014

\begin{tabular}{|c|c|c|c|c|}
\hline No & Tahun & JII & LQ 45 & IHSG \\
\hline 1 & 2009 & $92,97 \%$ & $84,39 \%$ & $86,98 \%$ \\
\hline 2 & 2010 & $27,74 \%$ & $32,73 \%$ & $46,13 \%$ \\
\hline 3 & 2011 & $0,78 \%$ & $1,83 \%$ & $3,20 \%$ \\
\hline 4 & 2012 & $10,76 \%$ & $9,13 \%$ & $12,94 \%$ \\
\hline 5 & 2013 & $-1,63 \%$ & $-3,25 \%$ & $-4,25 \%$ \\
\hline 6 & 2014 & $18,10 \%$ & $26,36 \%$ & $22,29 \%$ \\
\hline
\end{tabular}

Sumber : www.idx.co.id (diolah)

Berdasarkan data diatas, terjad fluktuasi indeks baik d JII LQ 45dan juga IHSG. Fenomena fluktuasi pertumbuhan indeks saham JII yang tidak konsisten ini menarik untuk dilakukan penelitian terutama sampai sejauh mana pengaruh makroekonomi pasca krisis global yang diwakili oleh suku bunga SBI, Jumlah Uang Beredar M2, perubahan tingkat inflasi, dan nilai tukar rupiah IDR/USD terhadap indek harga saham JII selama kurun waktu 2009-2014. 
Berfluktuasinya pergerakan indeks dalam industri pasar modal memang sudah seharusnya ditanggapi dengan serius olah para investor. Dalam prakteknya di lapangan, sudah menjadi kewajiban bagi para investor untuk memperhatikan segala situasi yang akan terjadi, baik itu situasi yang pasti maupun situasi tidak pasti. Khusus dalam keadaan tidak pasti, seorang investor dituntut untuk lebih berhati-hati. Jika tidak berhati-hati, kemungkinan keuntungan yang diharapkan untuk diperoleh akan berubah menjadi kerugian atau jauh lebih kecil daripada yang diharapkan. Berbagai risiko dapat menghadang serta menghancurkan investasi yang telah dengan susah payah dilakukan (Khalwaty, 2000 dalam Rusbariandi, 2012).

Selain itu, lingkungan ekonomi makro juga merupakan lingkungan ekonomi yang mempengaruhi operasi perusahaan sehari hari. Kemampuan investor dalam memahami dan meramalkan kondisi ekonomi makro dimasa datang akan sangat berguna dalam pembuatan keputusan investasi yang menguntungkan. Untuk itu, seorang investor harus mempertimbangkan beberapa indikator ekonomi makro yang bisa membantu investor dalam membuat keputusan investasinya. Indikator ekonomi makro yang sering dihubungkan dengan pasar modal adalah fluktuasi tingkat bunga, inflasi, kurs rupiah, pertumbuhan PDB (Kewal, 2012).

Ada beberapa studi yang berusaha menguji pengaruh indeks harga saham dan variabel makroekonomi baik secara regional maupun global. Hugida, (2011), Luthvi, (2014), Makaryanawati \& Ulum, (2009), Pasaribu \& Firdaus, (2013), Adib, (2009), Masodah, dkk, (2012), Indrasari, (2006), Nugroho, (2011), Novianto, (2011), Rusbariandi, (2012), Mugableh, (2012), Wijaya, (2013), Roza, (2012). Adalah beberapa studi yang menguji pengaruh variabel makroekonomi terhadap indeks harga saham serta return saham.

Pada studi studi tersebut, variabel makroekonomi yang digunakan adalah suku bunga SBI, yang terbukti memiliki hubungan atau pengaruh terhadap indeks harga saham (Makaryanawati \& Ulum, 2009). Hal ini juga sesuai dengan penelitian Luthvi (2014), Hugida (2011), Pasaribu \& Firdaus (2013), Roza, (2012), Hismendi, dan Hamzah \& Musnadi (2013). Peningkatan suku bunga SBI sebagai tingkat kenaikan bunga bebas resiko terbukti berpengaruh signifikan terhadap resiko investasi. Arah pengaruhnya sesuai/konsisten dengan teori yang menyatakan bahwa jika tingkat suku bunga tinggi, maka akan mengakibatkan harga saham turun dan resiko investasi menjadi menurun. Sebaliknya, jika tingkat suku bunga rendah, maka akan mengakibatkan harga saham naik dan resiko investasi menjadi menigkat. Namun demikian, beberapa penelitian lain Adib, (2009), Indrasari, (2006), Kewal, (2012), wijaya, (2013), menemukan bahwasanya suku bunga SBI tidak memiliki hubungan atau pengaruh terhadap indeks harga saham.

Selanjutnya nilai tukar dan harga saham dapat pula berpengaruh positif maupun negatif. Studi yang dilakukan Hugida, (2011), Nofiatin, (2013), Kristanti \& Lathifah, (2013), Novianto, (2011), Rusbariandi, (2012), Murtianingsih, (2012) menunjukkan hubungan positif antara kedua variabel. Namun menurut Kewal, (2012), Adib, (2009), Masodah, et al. (2012), Wijaya, (2013) menunjukkan bahwa hubungan antara kedua variabel tersebut negatif. Hal ini mengindikasikan bahwa ketika nilai tukar rupiah mengalami depresiasi maka investor akan mengalihkan dananya ke luar negeri sehingga terjadi capital outflow. Mengalirnya dana ke luar negeri menyebabkan investasi dalam 
Jurnal Ekonomi dan Perbankan Syariah

Vol. 3. No.2, 0ktober, 2015: 25--46, ISSN (cet): 2355-1755

negeri mengalami penurunan. Penurunan ini berdampak pada berkurangnya investasi pada saham di pasar domestik sehingga harga saham pun ikut mengalami penurunan.

Adapun tingkat inflasi dan indeks harga saham dapat pula berpengaruh positif maupun negatif. Studi yang dilakukan Luthvi, (2014), Masodah, (2012), Hugida, (2011), menunjukkan hubungan negatif antara kedua variabel. Mereka menyatakan bahwa naiknya inflasi mengindikasikan naiknya harga-harga barang konsumsi, yang berarti meningkatnya biaya hidup masyarakat. Hal ini membuat masyarakat memilih mengalokasikan dananya untuk konsumsi daripada investasi. Akibatnya, permintaan saham pada pasar modal akan mengalami penurunan. Rendahnya permintaan membuat harga saham akan turun. Akan tetapi penelitian tersebut berbeda dengan penelitian yang dilakukan oleh Amperaningrum \& Agung, (2011), Hugida, (2011).

Berbagai studi atau penelitian yang relevan dengan studi ini telah banyak dilakukan, namun dari berbagai penelitian tersebut menunjukkan bahwa periode observasi yang sama pada berbagai negara dengan model yang sama dapat menghasilkan kesimpulan yang tidak sama. Perbedaan periode observasi pada suatu negara dengan model yang sama juga dimungkinkan mendapatkan kesimpulan yang berbeda. Walaupun periode observasi dan negara sama, namun jika diterapkan dengan model dan metode berbeda, maka juga dimungkinkan mendapatkan kesimpulan yang berbeda pula.

\section{TELAAH PUSTAKA}

\section{Pengertian Pasar Modal Syariah}

Pasar modal merupakan salah satu alternatif bagi masyarakat untuk menginvestasikan hartanya. Pada tahapan ini, pasar modal tidak bertentangan dengan syariat Islam, di mana islam juga menganjurkan umatnya untuk melakukan investasi. Anjuran untuk melakukan investasi tersebut salah satunya dapat kita lihat dalam hadits berikut yang artinya:" Perdagangkanlah harta anak yatim agar harta tersebut tidak habis dimakan zakat" (HR. Malik dalam kitab al-Muwaththa") (Nashruddin, 2012).

Pasar modal islam/syariah dapat diartikan sebagai pasar modal yang menerapkan prinsip-prinsip hukum islam dalam kegiatan bisnis yang tidak melibatkan hal-hal dilarang oleh hukum islam seperti riba, perjudian, spekulasi, dll. Pasar modal islam sangat penting untuk mengembangkan islamic finance di dunia. Di pasar modal Islam, semua instrumen harus disetujui oleh Dewan Syariah Nasional (DSN). Dalam mengklasifikasikan surat-surat sekuritas, penasehat syariah akan mengumpulkan informasi untuk memutuskan semua sekuritas. Penasehat syariah mengumpulkan informasi dari perusahaan dari berbagai sumber, seperti laporan keuangan tahunan perusahaan, tanggapan perusahaan terhadap survei dan memeriksa setiap manajemen perusahaan (Ardiansyah \& Qoyum, 2012).

Masodah. Et all, (2012) pasar modal syariah adalah pasar modal yang dijalankan dengan prinsip prinsip syariah, setiap transaksi perdagangan surat berharga di pasar modal dilaksanakan sesuai dengan ketentuan syariat islam. Transaksi didalam pasar modal menurut prinsip syariah tidak dilarang (dibolehkan) sepanjang tidak terdapat transaksi yang bertentangan dengan ketentuan yang telah digariskan oleh syariah islam. Mekanisme penerbitan dan perdagangan efek di pasar modal mengikuti konsep pasar modal secara umum, kecuali untuk hal hal yang secara jelas dilarang secara syariah. 


\section{Prinsip Syariah Dalam Pasar Modal}

Dalam islam investasi merupakan kegiatan muamalah yang sangat dianjurkan, karena dengan berinvestasi harta yang dimiliki menjadi produktif dan juga mendatangkan manfaat bagi orang lain. Al-quran dengan tegas melarang aktifitas penimbunan (ikhtinaz) terhadap harta yang dimiliki. Untuk mengimplikasikan seruan investasi tersebut, maka harus diciptakan suatu sarana untuk berinvestasi. Banyak pilihan orang untuk menanamkan modalnya dalam bentuk investasi salah satu bentuk investasi adalah menanamkan harta nya di pasar modal (Roziq \& Mubarok, 2012).

Berdasarkan fatwa No.40/DSNMUI/X/2003 tentang pasar modal dan pedoman umum penerapan prinsip syariah di bidang pasar modal, menetapkan bahwa kriteria kegiatan usaha yang bertentangan dengan prinsip syariah ialah:

1. Usaha perjudian dan dan permainan yang tergolong judi atau perdagangan yang dilarang.

2. Lembaga keuangan konvensional (ribawi), termasuk perbankan dan asuransi konvensional.

3. Produsen, distributor serta pedagang makanan dan minuman haram.

4. Produsen, distributor, atau penyedia barang-barang ataupun jasa yang merusak moral dan bersifat mudarat.

5. Melakukan investasi pada emiten (perusahaan) yang pada saat transaksi tingkat (nisbah) hutang perusahaan kepada lembaga keuangan ribawi lebih dominan dari modalnya

\section{Fungsi Pasar Modal Syariah}

Fungsi dari keberadaan pasar modal syariah adalah sebagai berikut: (Rodoni \& hamid, 2008)

1. Memungkinkan bagi masyarakat untuk berpartisipasi dalam kegiatan bisnis dengan memperoleh bagian dari keuntungan dan resikonya.

2. Memungkinkan para pemegang saham menjual sahamnya guna mendapatkan likuiditas.

3. Memungkinkan perusahaan meningkatkan modal dari luar untuk membangun dan mengembangkan lini produknya.

4. Memisahkan operasi kegiatan bisnis dari fluktuasi jangka pendek pada harga saham yang merupakan ciri umum pada pasar modal konvensional.

5. Memungkinkan investasi pada ekonomi yang ditentukan oleh kinerja kegiatan bisnis sebagaimana tercermin pada harga saham.

\section{Karakteristik Pasar Modal Syariah}

Karakter yang diperlukan dalam membentuk struktur pasar modal syariah, dimana memungkinkan para pemegang saham individual dapat melepaskan sahamnya dan memperoleh keuntungan dengan adanya komitmen antara pemegang saham dengan perusahaan untuk tidak mencairkan sahamnya setidak tidaknya dalam jangka tiga bulan adalah sebagai berikut: Rodoni \& Ahmad, (2008).

a. Semua saham harus diperjual belikan pada bursa efek.

b. Bursa perlu mempersiapkan pasca perdagangan, dimana saham dapat diperjualbelikan melalui pialang.

c. Semua perusahaan yang mempunyai saham yang dapat diperjualbelikan pada bursa efek diminta menyampaikan informasi tentang perhitungan keuntungan dan 
Jurnal Ekonomi dan Perbankan Syariah

Vol. 3. No.2, 0ktober, 2015: 25--46, ISSN (cet): 2355-1755

kerugian serta neraca keuntungan kepada komite managemen bursa efek, dengan jangka waktu tidak lebih dari tiga bulan.

d. Komite manajemen menerapkan Harga Saham Tertinggi (HST) tiap tiap perusahaan dengan interval tidak lebih dari tiga bulan sekali.

e. Saham tidak boleh diperdagangkan dengan harga lebih tinggi dari HST.

f. HST ditetapkan dengan rumus : $\mathbf{H S T}=\frac{\text { Jumlah kekayaan bersih perusahaan }}{\text { Jumlah saham yang diterbitkan }}$

g. Perdagangan saham mestinya hanya berlangsung dalam satu minggu periode perdagangan setelah menentukan HST

h. Perusahaan hanya dapat menerbitkan saham dalam periode perdagangan dan dengan harga HST.

Khan (2005) dalam Rodoni \& Hamid, (2008) menambahkan, bahwa saham dan perdagangannya harus sesuai dengan prinsip prinsip keadilan dalam islam. Agar tercipta pasar saham yang adil, maka shareholder dilarang berpartisipasi dalam perdagangan dan tidak diperbolehkan untuk mempunyai orang yang bermain dalam pasar saham. Pasar saham juga harus bebas dari penipuan, praktik praktik yang dapat merugikan investor, seperti rekayasa informasi, pelarangan short selling, dan pencegahan adanya insider trading.

\section{Instrumen Pasar Modal Syariah}

Sektor keuangan yang berkembang dengan baik dapat mendorong perekonomian, akumulasi capital, dan peningkatan produktivitas. Efek efek yang boleh diperdagangkan dalam pasar modal syariah adalah yang hanya memenuhi kriteria syariah, seperti saham syariah, obligasi syariah, dan reksadana syariah (Rodoni \& Hamid, 2008). Di bawah ini merupakan produk-produk yang tergolong sebagai instrument pasar modal syariah, antara lain:

\section{a. Saham Syariah}

Saham merupakan instrumen pasar modal yang berupa surat bukti kepemilikan atas sebuah perusahaan yang melakukan penawaran umum (go public) dalam nominal ataupun persentase tertentu (Heykal, 2012). Di samping itu, dengan adanya aktifitas perdagangan saham di pasar sekunder pemegang saham dimungkinkan memperoleh capital gain yaitu selisih antara harga beli dengan harga jual saham. Namun, pemegang saham juga harus siap menghadapi resiko capital loss yang merupakan kebalikan dari capital gain serta risiko likuiditas, yaitu ketika perusahaan yang sahamnya dimiliki kemudian dinyatakan bangkrut oleh pengadilan, atau perusahaan tersebut dibubarkan, maka hak klaim dari pemegang saham mendapat prioritas terakhir setelah seluruh kewajiban perusahaan dapat dilunasi (dari hasil penjualan kekayaan perusahaan). Dengan demikian, keuntungan yang diperoleh dari memegang saham ini antara lain :

a. Deviden yang merupakan bagi hasil atas keuntungan yang dibagikan dari laba yang dihasilkan emiten, baik dibayarkan dalam bentuk tunai maupun dalam bentuk saham.

b. Rights yang merupakan hak untuk memesan efek lebih dahulu yang diberikan oleh emiten.

c. Capital gain yang merupakan keuntungan yang diperoleh dari jual beli saham di pasar modal. 
Sedangkan saham syariah adalah sertifikat yang menunjukkan bukti kepemilikan suatu perusahaan yang diterbitkan oleh emiten yang kegiatan usaha maupun cara pengelolaannya tidak bertentangan dengan prinsip prinsip syariah. Saham merupakan surat berharga yang mempresentasikan penyertaan modal ke dalam suatu perusahaan. Sementara dalam prinsip syariah, penyertaan modal dilakukan pada perusahaan perusahaan yang tidak melanggar prinsip prinsip syariah, seperti bidang perjudian, riba, memproduksi barang haram seperti minuman beralkohol dan lain lain (Soemitra, 2009). Di Indonesia, prinsip prinsip penyertaan modal secara syariah tidak diwujudkan dalam bentuk saham syariah maupun non syariah, melainkan berupa pembentukan indek saham yang memenuhi prinsip prinsip syariah ( Roziq \& Mubarok, 2012).

\section{b. Obligasi Syariah (Sukuk)}

Obligasi syariah yang juga dikenal dengan sukuk merupakan efek syariah berupa sertifikat atau bukti kepemilikan yang bernilai sama dan mewakili bagian penyertaan yang tidak terpisahkan atau tidak terbagi atas kepemilikan aset berwujud tertentu, nilai manfaat dan jasa atas aset aset proyek tertentu atau aktifitas investasi tertentu, serta kepemilikan atas aset proyek tertentu atau aktifitas investasi tertentu (Soemitra, 2009). Sedangkan obligasi syariah sesuai dengan fatwa DSN MUI No. 32/DSN-MUI/IX/2002 adalah suatu surat berharga jangka panjang berdasarkan prinsip syariah yang dikeluarkan emiten kepada pemegang obligasi syariah yang mewajibkan emiten untuk membayar pendapatan kepada pemegang obligasi syariah berupa bagi hasil, margin, fee, serta membayar kembali dana obligasi pada saat jatuh tempo.

Dalam mengembangkan sistem ekonomi syariah, penggunaan akad-akad menjadi prinsip yang membedakan antara ekonomi konvensional dengan ekonomi syariah. Akadakad yang digunakan dalam penerbitan obligasi syariah, antara lain:

1. Mudharabah, yaitu akad kerjasama antara dua pihak atau lebih, dimana satu pihak sebagai penyedia modal dan pihak lain sebagai penyedia tenaga dan keahlian, keuntungan dari kerjasama tersebut akan dibagi berdasarkan nisbah yang telah disetujui sebelumnya, sedangkan kerugian yang terjadi akan ditanggung oleh pemilik modal sepenuhnya, kecuali adanya kelalaian yang dilakukan oleh penyedia tenaga.

2. Murabahah, yaitu akad atau perjanjian jual-beli atas suatu barang dimana harga dan keuntungannya (profit margin) disetujui oleh semua pihak yang terlibat. Pembayarannya dapat dilakukan secara tunai, cicil atau tangguh, sedangkan penyerahan barang dilakukan di awal pada saat dilakukannya transaksi.

3. Salam, yaitu pemesanan barang dengan pembayaran dimuka, dengan spesifikasi tertentu dan penyerahan barang dikemudian hari.

4. Istishna', yaitu akad jual beli aset berupa obyek pembiayaan antara para pihak dimana spesifikasi, cara dan jangka waktu penyerahan, serta harga aset tersebut ditentukan berdasarkan kesepakatan para pihak.

5. Ijarah, yaitu akad pemindahan hak guna atas barang atau jasa, tanpa diikuti dengan pemindahan kepemilikan barang atau jasa itu sendiri.

\section{c. Reksa Dana Syariah}

Reksadana merupakan salah satu alternatif investasi bagi masyarakat pemodal, khususnya pemodal kecil dan pemodal yang tidak memiliki banyak waktu dan keahlian untuk menghitung resiko atas investasi mereka. Reksadana dirancang sebagai sarana 
Jurnal Ekonomi dan Perbankan Syariah

Vol. 3. No.2, 0ktober, 2015: 25--46, ISSN (cet): 2355-1755

untuk menghimpun dana dari masyarakat yang memiliki modal dan mempunyai keinginan untuk melakukan investasi, tetapi hanya memiliki waktu dan pengetahuan yang terbatas. Selain itu reksadana juga diharapkan dapat meningkatkan peran pemodal lokal untuk berinvestasi di pasar modal (Sudarsono, 2008).

Berdasarkan Fatwa DSN Nomor: 20/DSN-MUI/IX/2000 tanggal 18 April 2000 tentang Pedoman Pelaksanaan Investasi Untuk Reksadana Syariah telah mendefinisikan tentang reksadana syariah adalah reksadana yang beroperasi menurut ketentuan dan prinsip syariah Islam, baik dalam bentuk akad antara pemodal sebagai milik harta (shahib al-mal/rabbal-maal) dengan manajer investasi sebagai wakil shahib al-mal, maupun antara manajer investasi sebagai wakil shahib al-mal dengan pengguna investasi. Berdasarkan hal tersebut maka batasan untuk produk-produk yang dapat dijadikan portofolio bagi reksadana syariah adalah produk-produk investasi sesuai dengan ajaran Islam.

\section{Instrumen Yang dilarang Dalam Pasar Modal Syariah}

Adapun instrumen yang dilarang dalam pasar modal syariah adalah:

\section{Preferred Stock (saham istimewa)}

Saham (stock) adalah surat bukti kepemilikan atau bagian modal suatu perseroan terbatas yang dapat diperjual belikan baik di dalam maupun di luar pasar modal yang merupakan klaim atas penghasilan dan aktiva perusahaan. Ada beberapa jenis saham yang diterbitkan oleh emiten namun saham yang berkaitan dengan riba dayn yaitu saham istimewa (Tarmizi, 2013). Yang dimaksud dengan Saham istimewa adalah saham yang memberikan hak lebih besar daripada saham biasa dalam dividen pada waktu perseroan dilikuidasi (Rodoni \& Hamid, 2008).

Saham preferen karena sifatnya yang menjanjikan pendapatan tetap bagi pemegang saham maupun hak-hak istimewa lainnya yang bertentangan dengan prinsip dasar musyarakah di samping memasukkan unsur gharar (ketidakjelasan), maysir (spekulasi), dan riba (bunga), tidak diperkenankan secara syariah (Heykal, 2012). Dalam Majma' Al Fiqh Al Islami (divisi fikih OKI) mengeluarkan keputusan haram menerbitkan saham istimewa No. 63 (1/7) 1992, yang berbunyi, "Tidak boleh menerbitkan saham istimewa, pemegangnya mendapatkan hak jaminan dari emiten bahwa modalnya tidak akan berkurang serta mendapat deviden dalam jumlah tetap" (Tarmizi, 2013).

\section{Forward Contract}

Forward contract merupakan salah satu jenis transaksi yang diharamkan, karena bertentangan dengan syariah. Forward contract merupakan bentuk jual beli hutang yang di dalamnya terdapat unsur riba, sedangkan transaksi (jual beli) dilakukan sebelum tanggal jatuh tempo (Rodoni \& Hamid, 2008). Transaksi kontrak berjangka dalam bentuk forward dilakukan untuk memperoleh keuntungan atau mengurangi risiko yang disebabkan oleh ketidakpastian harga ataupun kuantitas produk perdagangan di masa datang. Produk yang diperdagangkan dapat berasal dari sektor riil maupun dari sektor finansial (Samsul, 2010). Hukum haramnya transaksi forward contract (transaksi berjangka) ini telah diputuskan oleh Al Majma' Al Fiqhy Al Islami (divisi fikih Rabhitah Alam Islami) dalam rapat tahunan ke-7 di Mekkah pada tahun $1404 \mathrm{H}$, yang berbunyi.'Transaksi berjangka yang dilakukan dengan cara barang tidak dimiliki (pinjaman), dimana saham atau barang yang dijual bukanlah milik penjual, sesuai aturan 
yang berlaku di pasar modal (bursa), maka hukumnya tidak dibolehkan syariat, karena transaksi ini termasuk menjual barang yang bukan miliknya, penjual hanya menyanggupi akan membeli barang, dan nanti akan diserahkan pada waktu yang telah diperjanjikan (Tarmizi, 2013).

\section{Option (kontrak opsi)}

Kontrak opsi merupakan transaksi yang terjadi pada hak untuk memilih dan menjual atau membeli sekuritas sehingga objeknya bukan sekuritas itu sendiri (Heykal, 2012). Dalam perdagangan option, buyer opsi memiliki hak untuk membeli (call option) dan hak untuk menjual (put option). Karena yang dimiliki bersifat hak, maka hak tersebut dapat dilaksanakan atau tidak dilaksanakan. Hak tersebut dilaksanakan apabila buyer merasa diuntungkan dan hak tidak dilaksanakan apabila buyer merasa dirugikan (Samsul, 2010). Transaksi dengan jenis option pada dasarnya jarang terselesaikan, karena biasanya diselesaikan dengan perolehan dari pembeli atas option atau penjualan yang terjadi dengan perbedaan harga, jika terjadi perbedaan maka keuntungan yang akan diperoleh, dan itu bukan karena adanya manfaat akan barang yang dimiliki. Prinsip syariah hanya mengizinkan terjadinya transaksi karena barang yang ditransaksikan akan memberikan manfaat bagi pihak pemiliknya (Heykal, 2012).

Haramnya transaksi opsi telah diputuskan oleh Majma' Al Fiqhy Al Islamy (divisi fikih OKI) No. 63 (1/7) tahun 1992, yang berbunyi”Kontrak opsi sebagaimana yang dipraktikkan di pasar modal merupakan akad baru yang tidak ada contohnya pada akad dahulu. Karena objek dalam transksi opsi bukanlah harta, bukan jasa dan juga bukan hak yang dapat diperjual belikan maka dari itu akad ini tidak dibolehkan syariat (Tarmizi, 2013)

\section{Transaksi Short Selling}

Transaksi ini merupakan suatu bentuk transaksi jual beli, dimana penjualan terhadap surat berharga belum dimiliki pada waktu akad. Transaksi ini dilarang dalam Islam karena memiliki unsur-unsur yang bersifat spekulatif dan penipuan. Adanya permainan harga secara short selling adalah ketika seseorang pembeli berupaya membeli suatu komoditas sebanyak mungkin, sehingga komoditi tersebut berkurang yang

pada gilirannya akan menyebabkan harga naik. Pada saat itulah ia akan melepas saham ke pasar sehingga memperoleh keuntungan yang banyak. Dampak dari adanya permainan harga inilah yang dapat membuat pasar menjadi tidak stabil, menyebabkan harga berfluktuasi, sehingga harga tidak menunjukkan nilai intrinsik saham sesungguhnya (Rodoni \& Hamid, 2008)

\section{Jual Beli Indek}

Yang dimaksud dengan jual beli indek adalah komitmen dua pihak yang bertransaksi agar salah satu pihak membayar kepada pihak lain sejumlah uang, selisih antara nilai indek pada tanggal yang disepakati sebagai hari serah terima dengan jumlah uang yang disepakati yang merupakan harga jual. Uang tersebut dibayarkan oleh penjual jika nilai indeks lebih tinggi dari harga beli atau dibayarkan oleh pembeli jika harga jual lebih tinggi dari nilai indek (Tarmizi, 2013)

Haramnya transaksi ini dinyatakan oleh Majma' Al Fiqhy Al Islamy dengan keputusan No. 63 (1/7) tahun 1992 M dalam muktamar ke VII di Jeddah yang berbunyi."Tidak boleh jual beli indek, karena jual beli tersebut murni perjudian dan objek yang diperjualbelikan dalam transaksi ini semu tidak pernah ada."(Tarmizi, 2013) 
Jurnal Ekonomi dan Perbankan Syariah

Vol. 3. No.2, 0ktober, 2015: 25--46, ISSN (cet): 2355-1755

\section{Pengertian Saham}

Saham (stock) adalah surat bukti kepemilikan atau bagian modal suatu perseroan terbatas yang dapat diperjual belikan baik di dalam maupun di luar pasar modal yang merupakan klaim atas penghasilan dan aktiva perusahaan (Tarmizi, 2013). Saham merupakan salah satu bentuk investasi yang paling populer. Saham diterbitkan oleh perusahaan guna mendapatkan modal. Saham berupa surat berharga bukti penyetoran dana dari investor kepada perusahaan. Perusahaan yang menerbitkan saham untuk dimiliki masyarakat disebut perusahaan terbuka (Go Public). Mekanisme perdagangan saham diatur oleh Bursa Efek Indonesia (BEI) di bawah pengawasan OJK (Otoritas Jasa Keuangan). Dalam berinvestasi khususnya pada saham, terdapat dua hal penting yaitu tingkat pengembalian atau imbal hasil (return) dan risiko. Investor umumnya menginginkan return yang maksimum dengan risiko yang minimum (Nastiti \& Suharsono, 2012).

Menurut (Rivai \& Buchari, 2013). Secara garis besar terdapat dua kategori saham yang umumnya dikenal dalam perdagangan saham yaitu saham preferen dan saham biasa. Saham preferen mempunyai hak klaim terhadap earning dan asset diperusahaan tempat mereka menginvestasikan dana, namun mereka tidak dapat memiliki hak suara dalam pemilihan direksi dan pengambilan keputusan perusahaan. Dan jika perusahaan bangkrut, klaim pemegang saham preferred akan didahulukan dalam pembayaran dibanding pemegang saham biasa. Sedangkan saham biasa mempunyai hak suara dalam pemilihan direksi dan keputusan yang berkenaan dengan perusahaan. Dividen yang diterima pemilik saham biasa mungkin saja lebih besar dengan pemilik saham preferred.

\section{Saham Syariah}

Saham syariah adalah kegiatan investasi berupa penyertaan modal yang dilakukan ke dalam perusahaan-perusahaan yang dalam kegiatannya tidak melanggar prinsip syariah (Heykal, 2012). Menurut Soemitro (2009) saham syariah adalah suatu saham yang dikeluarkan oleh suatu perusahaan yang telah memenuhi syarat - syarat sebagai berikut :

A. Jenis usaha, produk barang atau jasa yang diberikan dan akad serta cara pengelolaan perusahaan yang mengeluarkan saham (emiten) atau perusahaan publik yang menerbitkan saham syariah tidak boleh bertentangan dengan prinsip prinsip syariah. Jenis kegiatan usaha yang bertentangan dengan prinsip prinsip syariah antara lain: Perjudian dan permainan yang tergolong judi atau perdagangan yang dilarang;

1. Lembaga keuangan konvensional (ribawi), termasuk perbankan dan asuransi konvensional;

2. Produsen, distributor, dan/penyedia barang - barang ataupun jasa yang merusak moral dan bersifat mudharat;

3. Melakukan transaksi pada emiten yang pada saat transaksi tingkat hutang perusahaan kepada lembaga keuangan ribawi lebih dominan daripada modalnya;

4. Emiten atau perusahaan publik yang menerbitkan saham syariah wajib untuk menandatangani dan memenuhi ketentuan akad yang sesuai dengan syariah atas saham syariah yang dikeluarkan. 
36 | Ash-Shidiq \& Setiawan : Analisis Pengaruh Suku Bunga SBI, Uang Beredar, Inflasi dan Nilai Tukar......

B. Emiten atau perusahaan publik yang menerbitkan saham syariah wajib menjamin bahwa kegiatan usahanya memenuhi prinsip prinsip syariah (Fatwa DSN No. 40/2003).

\section{Indek Harga Saham}

Indeks harga saham adalah suatu indikator yang menunjukkan pergerakan harga saham. Indeks berfungsi sebagai indikator trend bursa saham yang menggambarkan kondisi pasar pada suatu kondisi tertentu, apakah pasar sedang aktif dan lesu, pergerakan indeks menjadi indikator penting bagi para investor untuk menentukan apakah mereka akan menjual, menahan, atau membeli saham dalam jumlah tertentu (Masodah, Et, all 2012).

Pergerakan nilai indeks akan menunjukkan perubahan situasi pasar yang terjadi. Pasar yang sedang positif atau terjadi transaksi yang aktif, ditunjukkan dengan indeks harga saham yang mengalami kenaikan. Keadaan stabil ditunjukkan dengan indeks harga saham yang tetap, sedangkan yang lesu ditunjukkan dengan indeks harga saham yang mengalami penurunan. Kondisi ini biasanya tidak disukai para investor karena dengan penurunan indeks harga saham akan menurunkan keuntungan mereka (Tesa, 2012).

Di Indonesia terdapat dua indeks saham syariah, yaitu JII dan ISSI. Yang membedakannya adalah JII merupakan indeks yang konstituennya hanya berjumlah 30 saham syariah ter likuid sedangkan ISSI konstituennya adalah seluruh saham syariah yang terdaftar di Bursa Efek Indonesia dan lolos dalam proses seleksi Daftar Efek Syariah (DES). Menurut Sudarsono, (2008) indeks harga saham merupakan indikator utama yang menggambarkan pergerakan harga saham. Di pasar modal sebuah indeks diharapkan memiliki lima fungsi yaitu :

1. Sebagai indikator trend saham

2. Sebagai indikator tingkat keuntungan

3. Sebagai tolak ukur (benchmark) kinerja suatu portofolio

4. Memfasilitasi pembentukan portofolio dengan startegi pasif

5. Memfasilitasi berkembangnya produk derivatif.

\section{Jakarta Islamic Index (JII)}

Jakarta Islamic Index (JII) merupakan salah satu indeks saham yang di Indonesia yang menghitung harga rata-rata untuk jenis saham yang memenuhi kriteria syariah yang tercantum dalam Dewan Pengawas Syariah dan peraturan Bapepam dan LK no IXA.A.13 (Wisambudi, Sudjana \& Topowijono, 2014). Menurut Rahmi \& Irfan (2012) Yang dimaksud dengan indeks adalah daftar harga sekarang dibandingkan dengan harga sebelumnya menurut persentase untuk mengetahui turun naiknya barang. Jadi, Jakarta Islamic Index atau biasa disebut JII adalah salah satu indeks saham yang ada di Indonesia yang menghitung indeks harga rata rata saham untuk jenis saham saham yang memenuhi kriteria syariah. Pembentukan JII tidak lepas dari kerja sama antara pasar modal Indonesia (dalam hal ini PT. Bursa Efek Jakarta) dengan PT. Danareksa Investment management (PT. DIM). JII telah dikembangkan sejak tanggal 3 Juli.

Tujuan pembentukan JII adalah untuk meningkatkan kepercayaan investor untuk melakukan investasi pada saham berbasis syariah dan memberikan manfaat bagi pemodal dalam menjalankan syariah Islam untuk melakukan investasi di Bursa. JII juga diharapkan dapat mendukung proses transparansi dan akuntabilitas saham berbasis syariah di Indonesia. (Istiqomah, 2012). JII menjadi jawaban atas keinginan investor 
Jurnal Ekonomi dan Perbankan Syariah

Vol. 3. No.2, 0ktober, 2015: 25--46, ISSN (cet): 2355-1755

yang ingin berinvestasi sesuai syariah. Dengan kata lain, JII menjadi pemandu bagi investor yang ingin menanamkan dananya secara syariah tanpa takut tercampur dengan dana ribawi. Selain itu, JII menjadi tolak ukur kinerja (benchmark) dalam memilih portofolio saham yang halal (Rahmi \& Irfan, 2012).

Saham syariah yang menjadi konstituen JII terdiri dari 30 saham yang merupakan saham saham syariah yang paling likuid dan memiliki kapitalisasi pasar yang besar. BEI melakukan review JII setiap 6 (enam) bulan, yang disesuaikan dengan periode penerbitan DES oleh Bapepam LK. Setelah dilakukan penyeleksian saham syariah oleh Bapepam LK yang dituangkan ke dalam DES, BEI melakukan proses seleksi lanjutan yang didasarkan kepada kinerja perdagangannya (Wulanditya, Salman \& Farid, 2012).

\section{METODE PENELITIAN}

\section{Jenis Penelitian}

Penelitian ini merupakan penelitian kuantitatif dengan pendekatan deskriptif. Dimana dalam penelitian kuantitatif menekankan pada pengujian teori teori melalui pengukuran variabel penelitian dengan angka dan melakukan analisis data statistik Indiantoro (2002) dalam Kurnia (2009). Pendekatan deskriptif adalah mengadakan kegiatan pengumpulan data dan analisis data dengan tujuan membuat deskriptif, gambaran secara sistematis, aktual, dan akurat mengenai fakta fakta, serta hubungan antara fenomena yang diselidiki Arikunto (2002) dalam Kurnia (2009).

\section{Jenis dan Sumber Data}

Jenis data yang digunakan dalam penelitian ini adalah data kuantitatif yaitu data yang diukur ke dalam suatu skala numerik (angka). Data kuantitatif disini berupa data runtut waktu (time series) yaitu data yang disusun menurut waktu pada suatu variabel tertentu (Apriansyah, 2014). Sedangkan menurut Makaryanawati \& Ulum, (2009), data kuantitatif adalah data berupa angka angka dan dalam data ini bisa dilakukan berbagai operasi matematika.

Populasi yang digunakan dalam penelitian ini adalah Jakarta Islamic Indeks (JII), tingkat suku bunga SBI, Jumlah Uang Beredar M2, inflasi, nilai tukar rupiah IDR/USD, dan Sedangkan data yang digunakan sebagai sampel dalam penelitian ini adalah data JII, tingkat suku bunga SBI, Jumlah Uang Beredar M2, inflasi, nilai tukar rupiah IDR/USD, yang dibatasi pada data penutupan tiap akhir bulan selama periode pengamatan Januari 2009 - Desember 2014. Data yang digunakan dalam penelitian ini bersumber dari situs www.idx.co.id berupa Jakarta Islamic Indeks (JII), kemudian dari www.bi.co.id berupa data tingkat inflasi, suku bunga SBI, nilai tukar rupiah terhadap Dollar. Sedangkan data Jumlah Uang Beredar M2 diperoleh dari www.bps.co.id. Semua data variabel yang diambil adalah berupa data runtun waktu (time series) bulanan mulai Januari 2009 sampai dengan Desember 2014.

\section{Teknik Analisis Data}

Penelitian ini menggunakan analisis regresi berganda. Data data yang diperoleh dari hasil penelitian selanjutnya dianalisis dengan model analisis regresi linear berganda menggunakan bantuan program Eviews 7 yang bertujuan untuk mengetahui seberapa besar pengaruh suku bunga SBI, Jumlah Uang Beredar M2, inflasi dan nilai tukar rupiah 
38 | Ash-Shidiq \& Setiawan : Analisis Pengaruh Suku Bunga SBI, Vang Beredar, Inflasi dan Nilai Tukar......

IDR/USD terhadap indek harga saham JII. Namun sebelum dilakukan analisis regresi berganda terlebih dahulu dianalisis statistik deskriptif dan uji asumsi klasik :

\section{Uji Asumsi Klasik}

Suatu model dikatakan baik untuk alat prediksi apabila mempunyai sifat-sifat tidak bias linear terbaik suatu penaksir. Di samping itu suatu model dikatakan cukup baik dan dapat dipakai untuk memprediksi apabila sudah lolos dari serangkaian uji asumsi klasik yang melandasinya (Ningsih, 2010). Uji Asumsi Klasik bertujuan untuk memastikan bahwa model regresi telah memenuhi asumsi dasar sehingga dapat digunakan untuk menguji hipotesis. Uji asumsi klasik perlu dilakukan karena dalam model regresi perlu memperhatikan adanya penyimpangan-penyimpangan atas asumsi klasik, karena pada hakikatnya jika asumsi klasik tidak dipenuhi maka variabel - variabel yang menjelaskan akan menjadi tidak efisien (Pramesthi, 2013). Uji Asumsi Klasik terdiri dari :
a. Uji Normalitas
b. Uji Multikolinearitas
c. Uji Heteroskedastisitas
d. Uji Autokorelasi

\section{Uji Regresi Linear Berganda}

Analisis regresi digunakan untuk mengetahui pengaruh variabel bebas dalam mempengaruhi variabel tidak bebas secara bersama-sama ataupun secara parsial. Persamaan regresi Linier Berganda dalam penelitian ini adalah :

$$
Y=a+b 1 X 1+b 2 X 2+b 3 X 3+e
$$

Keterangan :

Y : Variabel terikat (Indek Harga Saham JII)

$\mathrm{X} 1, \mathrm{X} 2, \mathrm{X} 3, \mathrm{X} 4$ :Variabel Bebas ( Suku bunga SBI, Jumlah Uang Beredar M2, Inflasi, Nilai Tukar Kurs)
a
: Konstanta
e
: Pengganggu (error)

\section{Pengujian Hipotesis}

1. Uji Koefisien Determinasi $\left(R^{2}\right)$

2. Uji Parsial (Uji t)

3. Uji F (simultan)

\section{HASIL DAN ANALISIS}

\section{Analisis Statistik Deskriptif}

Data yang digunakan dalam penelitian ini untuk masing masing variabel berjumlah 72 yang diperoleh dari 12 bulan dikalikan periode tahun pengamatan (6 tahun/dari tahun 2009-2014). Berikut ini adalah hasil statistik deskriptif dari data yang digunakan dalam penelitian ini :

Tabel 4. 1 Statistik Deskriptif

\begin{tabular}{|c|c|c|c|c|c|}
\hline & JII & INFLASI & SBI & M2 & KURS \\
\hline Mean & 531822.5 & 5.510556 & 6.359719 & 2856079. & 10006.08 \\
\hline Median & 542240.5 & 5.180000 & 6.700000 & 2852387. & 9596.500 \\
\hline
\end{tabular}


Jurnal Ekonomi dan Perbankan Syariah

Vol. 3. No.2, 0ktober, 2015: 25--46, ISSN (cet): 2355-1755

\begin{tabular}{|c|c|c|c|c|c|}
\hline Maximum & 691132.0 & 9.170000 & 10.52000 & 4170731. & 12385.00 \\
\hline Minimum & 213634.0 & 2.410000 & 3.822900 & 1859891. & 8508.000 \\
\hline Std. Dev. & 117979.8 & 1.792268 & 1.295958 & 688795.0 & 1187.040 \\
\hline Skewness & -0.877179 & 0.311846 & 0.210459 & 0.193553 & 0.699376 \\
\hline Kurtosis & 3.359884 & 2.081494 & 3.836088 & 1.729185 & 2.039220 \\
\hline Jarque-Bera & 9.621864 & 3.697932 & 2.628644 & 5.294463 & 8.638814 \\
\hline Probability & 0.008140 & 0.157400 & 0.268656 & 0.070847 & 0.013308 \\
\hline Sum & 38291222 & 396.7600 & 457.8998 & $2.06 \mathrm{E}+08$ & 720438.0 \\
\hline Sum Sq. Dev. & $9.88 \mathrm{E}+11$ & 228.0680 & 119.2450 & $3.37 \mathrm{E}+13$ & $1.00 \mathrm{E}+08$ \\
\hline Observations & 72 & 72 & 72 & 72 & 72 \\
\hline
\end{tabular}

Berdasarkan tabel di atas terlihat bahwa tingkat inflasi periode tahun 2009-2014 (bulan Januari 2009 - Desember 2014) rata rata sebesar 5,51\%. Nilai maksimum sebesar 9,17\% nilai minimum sebesar 2,41\%., dengan standar deviasi sebesar 1,79\%. Tingkat suku bunga SBI yang merupakan surat berharga yang dikeluarkan Bank Indonesia sebagai pengakuan hutang berjangka waktu pendek (1-3) dengan sistem diskonto atau bunga. Rata rata tingkat suku bunga SBI periode 2009 - 2014 berada pada posisi 6,36\% dengan nilai maksimum sebesar 10,52\%, dan minimum sebesar 3,82\%. Sedangkan standar deviasi sebesar 1,30\%. Nilai tukar yang merupakan sejumlah uang dari suatu mata uang tertentu yang dapat dipertukarkan dengan satu unit mata uang negara lain, yang dalam hal ini rupiah terhadap US Dollar. Sedangkan, rata rata nilai tukar periode tahun 2009 - 2014 (Januari 2009 - Desember 2014) adalah sebesar 10,01\%. Nilai maksimum sebesar 12,39\% nilai minimum sebesar 8,51\% dengan standar deviasi sebesar 1,19\%. Selanjutnya, nilai rata rata dari Jumlah Uang Beredar M2 adalah sebesar $28,56 \%$ dengan nilai maksimumnya 41,71 dan nilai minimumnya sebesar $18,50 \%$ dengan standar deviasi sebesar $68.88 \%$.

JII yang merupakan suatu nilai yang digunakan untuk mengukur kinerja saham syariah yang tercatat di BEI. Berdasarkan tabel di atas didapatkan bahwa rata rata JII periode tahun 2009 -2014 adalah sebesar 531,822. Nilai maksimum 691,132 dan nilai minimum sebesar 213,634 dengan standar deviasinya sebesar 117,979.

\section{Analisis Uji Asumsi Klasik}

Uji asumsi klasik perlu dilakukan karena dalam model regresi perlu memperhatikan adanya penyimpangan-penyimpangan atas asumsi klasik, karena pada hakikatnya jika asumsi klasik tidak dipenuhi, maka variabel - variabel yang menjelaskan akan menjadi tidak efisien. Setelah melakukan Uji asumsi klasik ternyata terdapat data yang ada terdapat auokorelasi maka perlu diatasi terlebih dahulu. Untuk mengatasi apabila terjadi autokorelasi dalam penelitian ini dapat digunakan beberapa teknik yaitu (1) jika koefisien autokorelasi tinggi maka dapat digunakan metode transformasi / diferensi tingkat pertama, (2) jika koefisien autokorelasi rendah maka dapat digunakan metode Ordinary Least Square (OLS) dan (3) jika koefisien tidak diketahui maka dapat menggunakan metode Chochrane-Orcutt. Adapun dalam penelitian ini, menggunakan teknik atau metode transformasi differensiasi. Sehingga perlu dilakukan kembali macam macam uji asumsi klasik yang terdiri dari uji normalitas, multikolinearitas, heteroskedastisitas dan autokorelasi. 
40 | Ash-Shidiq \& Setiawan : Analisis Pengaruh Suku Bunga SBI, Uang Beredar, Inflasi dan Nilai Tukar......

\section{Uji Normalitas Differensi}

\section{Grafik 4. 1 Uji Normalitas}

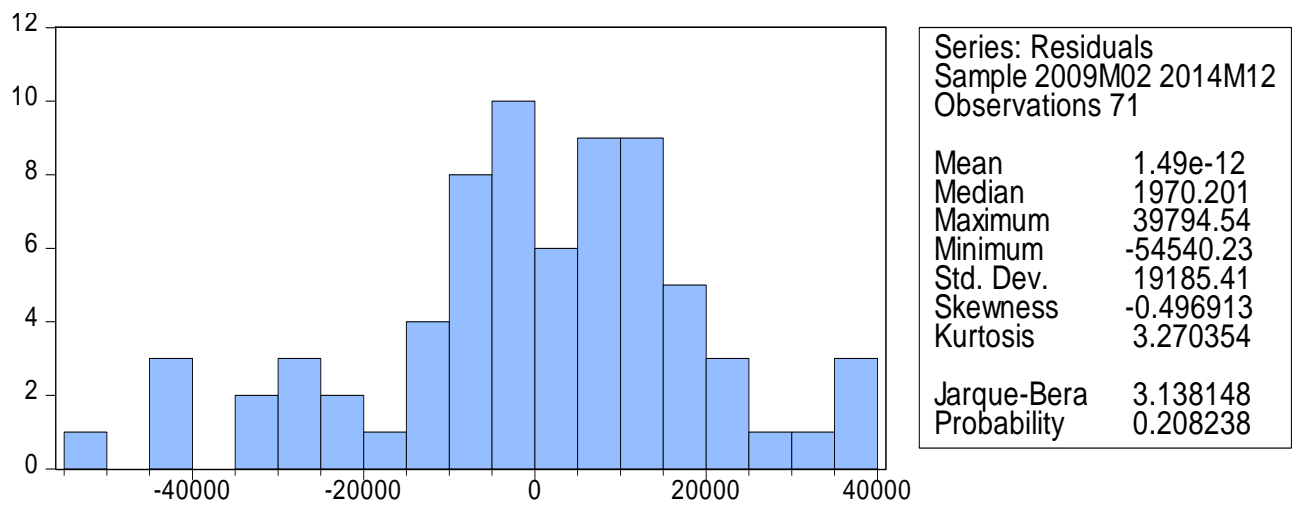

Hasil uji normalitas dengan $J-B$ test didapatkan nilai probabilitasnya sebesar 0,208238 . Dengan demikian, karena nilai probabilitasnya sebesar 0,208238 > $\alpha(5 \%)$, maka disimpulkan data berdistribusi secara normal.

Uji Heteroskedastisitas Differensi

Tabel 4. 2 Uji Heteroskedastisitas

\begin{tabular}{llll}
\hline \hline F-statistic & 0.672107 & Prob. F(14,56) & 0.7910 \\
Obs*R-squared & 10.21372 & Prob. Chi-Square(14) & 0.7464 \\
Scaled explained SS & 10.01887 & Prob. Chi-Square(14) & 0.7608 \\
\hline \hline
\end{tabular}

Hasil perhitungan uji heteroskedastisitas dengan menggunakan uji white menghasilkan kesimpulan tidak ada masalah heteroskedastisitas atau dapat dikatakan data bersifat homoskedastisitas. Hal ini dibuktikan dengan nilai probabilitas observasi $\mathrm{R}^{2}$ sebesar 0,7464 lebih besar dari 0,05. Itu artinya tidak ada heteroskedastisitas. Hal ini berarti penelitian dapat dilanjutkan.

\section{Uji Multikolinearitas Differensi}

Untuk mendeteksi gejala multikolinearitas digunakan pengolahan data pada softwere Eviews 7. Dengan ketentuan jika korelasi antar variabel lebih kecil dari 0,8 (< 0,8 ), maka tidak terdapat masalah multikolinearitas pada model regresi. Korelasi tergolong kuat jika besarnya 0,8 atau lebih

Tabel 4. 3 Uji multikolinearitas

\begin{tabular}{|l|l|l|l|l|}
\hline & SBI & M2 & INFLASI & KURS \\
\hline SBI & 1.000000 & -0.301879 & 0.447366 & 0.405426 \\
\hline JUB M2 & -0.301879 & 1.000000 & 0.320661 & 0.591712 \\
\hline INFLASI & 0.447366 & 0.320661 & 1.000000 & 0.526639 \\
\hline KURS & 0.405426 & 0.591712 & 0.526639 & 1.000000 \\
\hline
\end{tabular}

Berdasarkan hasil pengujian pada tabel 4.6, menunjukkan bahwa secara umum multikolinearitas dapat dideteksi dari ada tidaknya hubungan yang signifikan antar 
Jurnal Ekonomi dan Perbankan Syariah

Vol. 3. No.2, 0ktober, 2015: 25--46, ISSN (cet): 2355-1755

variabel bebas. Caranya dengan membandingkan korelasi (r) parsial variabel SBI, M2, inflasi dan nilai tukar rupiah IDR/USD , apakah > atau < dari korelasi regresi (R). Korelasi $\mathrm{R}$ adalah akar dari $\mathrm{R}^{2}$ atau jika $\mathrm{r}<0,8$ berarti tidak terjadi multikolinearitas (Sriwijaya, 2013).

\section{Uji Autokorelasi Differensi}

Berikut hasil uji Autokorelasi differensi pada penelitian ini

Tabel 4. 4 Uji Autokorelasi

\begin{tabular}{llll}
\hline \hline F-statistic & 2.317949 & Prob. F(2,64) & 0.1067 \\
Obs*R-squared & 4.795577 & Prob. Chi-Square(2) & 0.0909 \\
\hline \hline
\end{tabular}

Berdasarkan hasil Uji Autokorelasi dengan menggunakan metode uji BreuschGodfrey setelah dilakukan transformasi differensi di atas menunjukkan bahwa nilai probabilitas nya bernilai 0,0909 Itu artinya tidak ada autokorelasi karena p value > 0,05. Menurut Sriwijaya, (2013) autokorelasi muncul karena observasi yang beruntun sepanjang waktu berkaitan satu sama lain. Model regresi yang baik adalah regresi yang bebas dari autokorelasi. Masalah ini timbul karena residu (kesalahan pengganggu) tidak bebas dari satu observasi lainnya hal ini sering ditemukan pada data time series. Itu arti nya penelitian ini terbebas dari masalah autokorelasi dan layak untuk dilanjutkan.

\section{Analisis Regresi Linear Berganda dan Hasil Pengujian Hipotesis Koefisien Determinasi $\left(R^{2}\right)$}

Koefisien determinan digunakan untuk mengukur seberapa jauh kemampuan model dalam menerangkan variasi variabel variabel dependen. Nilai koefisien adalah antara nol sampai dengan satu dan ditunjukkan dengan nilai adjusted $R^{2}$. Dan berdasarkan hasil penelitian ini menunjukkan bahwa nilai koefisien determinan $\left(\mathrm{R}^{2}\right)$ diperoleh sebesar 0,333700 atau 33,37 \%. Hal ini menunjukkan bahwa 33,37 \% kinerja JII dipengaruhi oleh variabel suku bunga SBI, Jumlah Uang Beredar M2, inflasi dan nilai tukar rupiah IDR/USD. Sedangkan sisanya sebesar 66,63 \% dijelaskan oleh variabel lain. Adapun hasil tersebut dapat dilihat pada tabel di bawah ini

Tabel 4. 5 Hasil Uji Determinan (R2)

\begin{tabular}{lllll}
\hline \hline Variable & Coefficient & Std. Error & t-Statistic & Prob. \\
\hline \hline C & 5468.095 & 3040.856 & 1.798209 & 0.0767 \\
D(SBI) & 2436.642 & 8016.850 & 0.303940 & 0.7621 \\
D(M2) & 0.065173 & 0.058852 & 1.107411 & 0.2721 \\
D(INFLASI) & -3965.264 & 3408.422 & -1.163372 & 0.2489 \\
D(KURS) & -54.20321 & 9.961214 & -5.441426 & 0.0000 \\
\hline \hline R-squared & 0.371774 & Mean dependent var & 6724.014 \\
Adjusted R-squared & 0.333700 & S.D. dependent var & 24205.45 \\
S.E. of regression & 19758.24 & Akaike info criterion & 22.68835 \\
Sum squared resid & $2.58 E+10$ & Schwarz criterion & 22.84769 \\
Log likelihood & -800.4364 & Hannan-Quinn criter. & 22.75171
\end{tabular}


42 | Ash-Shidiq \& Setiawan : Analisis Pengaruh Suku Bunga SBI, Uang Beredar, Inflasi dan Nilai Tukar......

$\begin{array}{llll}\text { F-statistic } & 9.764435 & \text { Durbin-Watson stat } & 2.212894 \\ \text { Prob(F-statistic) } & 0.000003 & \end{array}$

\section{Pengujian Terhadap Koefisien Regresi Secara Parsial (Uji t) a. Pengujian terhadap variabel suku bunga SBI}

Hipotesis pertama menyebutkan bahwa SBI berpengaruh signifikan terhadap JII. Berdasarkan hasil perhitungan data menggunakan program Eviews 7. Diperoleh hasil bahwa nilai signifikansi sebesar 0,7621 ini berarti H0 diterima dan tolak Ha, artinya SBI tidak berpengaruh signifikan terhadap JII karena nilai signifikansi lebih besar dari 0,05.

Hasil penelitian ini berbeda dengan teori yang dipakai dalam penelitian ini yaitu Apabila tingkat suku bunga naik maka secara langsung akan meningkatkan beban bunga, Perusahaan yang mempunyai leverage yang tinggi akan mendapatkan dampak yang sangat berat terhadap kenaikan tingkat bunga. Kenaikan tingkat bunga ini dapat mengurangi profitabilitas perusahaan sehingga dapat memberikan pengaruh terhadap harga saham perusahaan yang bersangkutan.

Hasil penelitian ini mendukung hasil penelitian penelitian sebelumnya yaitu yang dilakukan oleh Kewal, (2012). Kriswanto, (2014) dan Amperaningrum \& Agung, (2011) menunjukkan suku bunga SBI tidak berpengaruh secara signifikan terhadap IHSG. Sedangkan hasil berbeda disampaikan oleh Amin, (2012), Hismendi, Hamzah \& Musnadi, (2013), yang menunjukkan hasil sebaliknya yaitu terdapat pengaruh SBI terhadap IHSG.

\section{b. Pengujian Terhadap Variabel Jumlah Uang Beredar (M2)}

Hipotesis pengaruh variabel Jumlah Uang Beredar (M2) terhadap indek harga saham JII di Bursa Efek Indonesia yang digunakan adalah : 1). H0 : b2 = 0 berarti Jumlah Uang Beredar (M2) tidak berpengaruh signifikan terhadap indek harga saham JII di Bursa Efek Indonesia. 2). Ha : b2 $\neq 0$ berarti Jumlah Uang Beredar (M2) berpengaruh signifikan terhadap indek harga saham JII di Bursa Efek Indonesia. Hasil perhitungan melalui program Eviews 7 untuk variabel Jumlah Uang Beredar (M2) diperoleh nilai probabilitas 0,2721 . Dengan demikian Ha ditolak, karena nilai probabilitas lebih dari $\alpha$ $0,05(0,2721>0,05)$. Berarti dapat disimpulkan bahwa Jumlah Uang Beredar (M2) tidak berpengaruh signifikan terhadap indek harga saham JII di Bursa Efek Indonesia.

Hasil penelitian ini berbeda dengan teori yang dipakai dalam penelitian ini yaitu terdapat tiga macam tujuan seseorang memegang uang tunai, yaitu motif transaksi, berjaga-jaga dan spekulasi. Permintaan uang tunai untuk tujuan transaksi menunjukkan jumlah uang tunai yang diminta untuk tujuan membiayai transaksi/pengeluaran yang sifatnya tertentu (perbulan) membayar dalam jumlah tetap dan rutin. Permintaan uang tunai untuk berjaga-jaga menunjukkan uang tunai yang diminta untuk bertujuan untuk tujuan membiayai transaksi/pengeluaran yang sifatnya bukan rutin dan bukan spekulatif (Nugroho, 2008).

Adapun hasil penelitian ini mendukung hasil dari penelitian penelitian sebelumnya yang dilakukan oleh Kurniadi,(2013), Wijaya, (2013), Wastriadi, (2010) menunjukkan tidak terdapat pengaruh Jumlah Uang Beredar M2 terhadap JII. Hasil berbeda dan bertentangan yang ditemukan oleh Beik \& Fatmawati, (2014), Passaribu \& Firdaus, (2013) yang menunjukkan hasil sebaliknya.

\section{c. Pengujian Terhadap variabel Inflasi}


Jurnal Ekonomi dan Perbankan Syariah

Vol. 3. No.2, 0ktober, 2015: 25--46, ISSN (cet): 2355-1755

| 43

Hipotesis pengaruh variabel inflasi terhadap indek harga saham JII di Bursa Efek Indonesia yang digunakan adalah : 1). H0 : b3 $=0$ berarti inflasi tidak berpengaruh signifikan terhadap indek harga saham JII di Bursa Efek Indonesia. 2). Ha : b3 $\neq 0$ berarti inflasi berpengaruh signifikan terhadap indek harga saham JII di Bursa Efek Indonesia. Hasil perhitungan melalui program Eviews 7 untuk variabel inflasi diperoleh nilai probabilitas 0,2489 . Dengan demikian Ha ditolak, karena nilai probabilitas lebih dari $\alpha$ $0,05(0,2489>0,05)$. Berarti dapat disimpulkan bahwa inflasi tidak berpengaruh signifikan terhadap indek harga saham JII di Bursa Efek Indonesia.

Hasil penelitian ini berbeda dengan teori yang digunakan dalam penelitian ini yaitu inflasi merupakan kenaikan harga yang terjadi secara umum dan secara terus menerus. Jika terjadi inflasi maka akan meningkatkan biaya produksi barang dan jasa sehingga dapat meenyebabkan menurunnya profit yang dihasilkan oleh perusahaan tersebut. Menurunnya profit akan berdampak pada penurunan deviden dan juga return. Hal tersebut akan menurunkan expected return sehingga dapat menyebabkan penurunan permintaan akan saham suatu perusahaan. Penurunan permintaan akan saham akan menyebabkan penurunan harga saham dan berdampak pada penurunan indek harga saham (Pranandari, 2015). Turunnya nilai saham akan berakibat pada Ruginya investor yang bisa beimbas pada capital outflow ke pasar uang ataupun ke pasar modal luar negeri (Tesa, 2012).

Hasil ini mendukung penelitian yang telah dilakukan oleh Maqdiyah, Rahayu \& Topowijono, (2014), Pranandari, (2015), Kewal, (2012), Amin, (2012), Hismendi, Hamzah \& Musnadi, (2013) yang menunjukkan inflasi tidak berpengaruh terhadap JII. Adapun hasil berbeda disampaikan oleh Rusbariandi, (2013), Kristanti \& Lathifah, (2013), Mulyani, (2014), Suciningtias \& Khoiroh, (2015) yang menyatakan bahwa inflasi berpengaruh terhadap indek harga saham.

\section{d. Pengujian Terhadap Variabel Nilai Tukar Rupiah IDR/USD}

Hipotesis pengaruh variabel nilai tukar rupiah IDR/USD terhadap indek harga saham JII di Bursa Efek Indonesia yang digunakan adalah : 1). H0 : b4 = 0 berarti nilai tukar rupiah IDR/USD tidak berpengaruh signifikan terhadap indek harga saham JII di Bursa Efek Indonesia. 2). Ha : b4 $\neq 0$ berarti nilai kurs berpengaruh signifikan terhadap indek harga saham JII di Bursa Efek Indonesia. Hasil perhitungan melalui program Eviews 7 untuk variabel nilai tukar rupiah diperoleh nilai probabilitas 0,0000 . Dengan demikian Ha diterima, karena nilai probabilitas kurang dari $\alpha 0,05(0,0000<0,05)$. Berarti dapat disimpulkan bahwa nilai tukar rupiah berpengaruh signifikan terhadap indek harga saham JII di Bursa Efek Indonesia.

hasil penelitian ini mendukung teori yang digunakan dalam penelitian ini yaitu depresiasi rupiah terhadap dollar berarti bahwa nilai rupiah mengalami pelemahan sehingga penukaran mata uang dollar akan mendapatkan nilai rupiah yang lebih tinggi. Pelemahan nilai tukar rupiah akan berpengaruh secara berbeda terhadap perusahaan dalam katagori impor atau ekspor. Bagi perusahaan impor tentu depresiasinya rupiah akan merugikan perusahaan sebab menanggung biaya yang lebih besar. Hal yang sama juga dialami oleh perusahaan yang memiliki hutang dalam bentuk dolar tentu depresiasi rupiah akan merugikan sebab perusahaan akan membayar kewajiban yang lebih besar, 
tentu hal tersebut akan menurunkan profitabilitas perusahaan. Ketika profitabilitas perusahaan turun, banyak investor yang memilih untuk menjual sahamnya dan memilih beralih pada investasi lainnya seperti pada pasar valuta asing. Sikap para investor tersebut yang mampu menurunkan harga saham perusahan serta berpengaruh pada permintaan saham - saham di Bursa Efek Indonesia (BEI) termasuk saham syariah pada indeks Jakarta Islamic Index (JII) sehingga berakibat pada pergerakan indeks saham yang menurun.

Hasil ini mendukung penelitian yang telah dilakukan oleh Novianto, (2011), Hayati, (2011), Rusbariandi, (2013), Wijaya, (2013), Maqdiyah, Rahayu \& Topowijono, (2014) \& Mulyani, (2014) menunjukkan nilai tukar berpengaruh negatif signifikan tehadap JII.

\section{Pengujian Terhadap Koefisien Regresi Secara Simultan (Uji F)}

Dari hasil pengujian data maka diperoleh hasil Uji $\mathrm{F}$, hasil pengujian data di atas diperoleh data dengan nilai probabilitas (F-statistik) < $\alpha$ yaitu sebesar 0,000003 , dengan demikian Ha diterima karena nilai probabilitas kurang dari $\alpha 0,05(0,000003<0,05)$ maka dari keempat variabel (SBI, M2, inflasi, nilai tukar rupiah IDR/USD) secara bersama sama berpengaruh terhadap indek harga saham JII di Bursa Efek Indonesia.

\section{SIMPULAN}

Berdasarkan hasil penelitian yang telah dilakukan maka pada penelitian ini dapat ditarik kesimpulan, bahwa Variabel suku bunga SBI, Uang Beredar M2, Inflasi, tidak berpengaruh signifikan terhadap indek harga saham Jakarta Islamic Index (JII). Sedangkan variabel nilai tukar rupiah IDR/USD mempunyai pengaruh negatif signifikan tehadap indek harga saham Jakarta Islamic Index (JII) selama periode Januari 2009 sampai dengan Desember 2014. Dimana semakin tinggi tinggi tingkat Kurs Rupiah maka akan menurunkan Jakarta Islamic Index (JII).

Berdasarkan nilai adjusted R2 sebesar 0,333700 atau 33,37 \%. Hal ini berarti sebesar 33,37 \% variabel Jakarta Islamic Index (JII) dapat dipengaruhi oleh suku bunga SBI, jumlah uang beredar M2, inflasi dan nilai tukar rupiah IDR/USD, sedangkan sisanya sebesar 66,63 \% Jakarta Islamic Index (JII) dapat dijelaskan oleh variabel lain di luar model penelitian. Dilihat dari nilai adjusted R2 bahwa pengaruh variabel independen terhadap variabel dependen tergolong lema

\section{DAFTAR PUSTAKA}

Adib, Ahmad M. (2009). Pengaruh Inflasi, Suku Bunga Domestik, Suku Bunga Luar Negri dan Kurs Terhadap Indek Harga Saham. Studi Pada JII dan IHSG tahun 2005-2007: Skripsi Program Studi keuangan Islam Jurusan Muamalah Fakultas Syariah Universitas Islam Negri Sunan Kalijaga. Yogyakarta

Amin, M. Z. (2012). Pengaruh Tingkat Inflasi, Suku Bunga SBI, Nilai Kurs Dollar (USD/IDR), dan Indeks Dow Jones (DJIA) Terhadap Pergerakan Indek Harga Saham Gabungan di Bursa Efek Indonesia : Jurnal Skripsi FEB UB. Malang

Amperaningrum, Izzati \& Robby Suryawan A. (2011) Pengaruh Tingkat Suku Bunga SBI, Nilai Tukar Mata Uang dan Tingkat Inflasi Terhadap Perubahan Harga Saham Sub Sektor Perbankan di Bursa Efek Indonesia : Jurnal Universitas Gunadarma Depok Vol. 4

Antonio, M Syafii, Hafindhoh \& Hilman Fauzi. (2013). The Islamic Capital Market Volatility A Comparative Study Between In Indonesia And Malaysia : Jurnal Liquidity Vol. 2, No. 1 hlm 1 - 12 
Jurnal Ekonomi dan Perbankan Syariah

Vol. 3. No.2, 0ktober, 2015: 25--46, ISSN (cet): 2355-1755

Beik, Irfan Syauqi \& Sri Wulan Fatmawati. (2014). Pengaruh Indeks Harga Saham Syariah Internasional dan Variabel Makro Ekonomi Terhadap Jakarta Islamic Indeks: Jurnal Al-Iqtishad Vol. VI No. 2

DSN MUI, Pasar Modal dan Pedoman Umum Penerapan Prinsip Syariah di Bidang Pasar Modal, Fatwa DSN MUI. No 40/DSN-MUI/X/2003 Tentang

Pasar Modal dan Pedoman Umum Penerapan Prinsip Syariah di Bidang Pasar Modal

DSN MUI, Pedoman Pelaksanaan Investasi Untuk Reksadana Syariah, Fatwa DSN MUI NO. 20/DSN-MUI/IX/2003 Tentang Pedoman Pelaksanaan Investasi Untuk Reksadana Syariah

Heykal, Mohamad. (2012). Tuntunan dan Aplikasi Investasi Syariah. Penerbit : PT Elex Media Komputindo. Jakarta

Hismendi, Abubakar Hamzah \& Said Musnadi. (2013). Analisis Pengaruh Nilai Tukar, SBI, Inflasi dan Pertumbuhan GDP Terhadap Pergerakan Indek Harga Saham Gabungan Di Bursa Efek Indonesia : Jurnal Ilmu Ekonomi Pasca Sarjana Universitas Syiah Kuala. Vol. 1, No. 2, 16-28

Hugida, Lydianita. (2011). Analisis Faktor Faktor Yang Mempengaruhi Volatilitas Harga Saham (Studi pada Perusahaan Yang Terdaftar Dalam Indek LQ45 periode 2006 2009) : Skripsi Fakultas Ekonomi Universitas di Ponegoro. Semarang

Indrasari, Ratih. (2006). Analisis Pengaruh Return on Asset, Volume Perdagangan, Earning per share dan tingkat suku Bunga Terhadap Harga Saham Perusahaan Yang Terdaftar di Jakarta Islamic Indek Bursa Efek Indonesia : Skripsi Fakultas Ekonomi Universitas Sebelas Maret. Surakarta

Istiqomah. (2012). Dinamika Interaksi Antara Variabel Moneter dan Pasar Modal Syariah Terhadap Pertumbuhan Ekonomi Indonesia : Skripsi Departemen Ilmu Ekonomi Fakultas Ekonomi dan Manajemen Institut Pertanian Bogor. Bogor

Kewal, Suramaya S. (2012). Pengaruh Inflasi, Suku Bunga, Kurs, dan Pertumbuhan PDB Terhadap Indek Harga Saham Gabungan : Jurnal Economia Vol. 8 No. 1

Kristanti, Farida, T \& Nur Taufikoh L. (2013). Pengujian Variabel Makro Ekonomi Terhadap Jakarta Islamic Indek (JII) : Jurnal Keuangan dan Perbankan Vol. 17 No. 1

Kurniadi, Rachmat. (2013). Analisis Pengaruh Nilai Tukar, Suku Bunga SBI,dan Jumlah Uang Beredar Terhadap Harga Saham Sektor Properti di Bursa Efek Indonesia (BEI) Periode 2006 - 2011 : Skripsi Jurusan Ilmu Ekonomi dan Studi Pembangunan Fakultas Ekonomi dan Bisnis Universitas Islam Negeri Syarif Hidayatullah. Jakarta

Luthvi, Dani A. (2014). Pengaruh Suku Bunga SBI, Inflasi, Pertumbuhan Ekonomi, dan Size terhadap Return Saham Syariah di Jakarta Islamic Indek (JII) Periode 2009- 2013 : Skripsi Program Studi Manajemen Fakultas Ekonomi Universitas Negeri Yogyakarta. Yogyakarta

Makaryanawati dan Misbachul Ulum. (2009). Pengaruh TingkatSuku Bunga dan Tingkat Likuiditas Perusahaan terhadap Risiko Investasi Saham yang Terdaftar pada Jakarta Islamic Indeks : Jurnal Ekonomi Bisnis. Tahun 14, No. 1

Maqdiyah, Hatmam, Topowijono \& Sri Mangesti. (2014). Pengaruh Tingkat Bunga Deposito, Tingkat Inflasi, Produk Domestik Bruto, dan Nilai Tukar Rupiah Terhadap Indeks Harga Saham Jakarta Islamic Indek (JII) di Bursa Efek Indonesia 2009 hingga 2013: Jurnal Administrasi Bisnis (JAB) Vol. 17 No. 2

Masodah, et. al, ed. (2012). Analisis Pengaruh Tingkat Inflasi, Harga Minyak Dunia, Harga Emas Dunia, dan Kurs Rupiah Terhadap Pergerakan Jakarta Islamic Indek di Bursa Efek Indonesia : Prosiding Seminar Nasional Forum Bisnis dan Keuangan I

Mulyani, Neni. (2014). Analisis Pengaruh Inflasi, Suku Bunga, Nilai Tukar Rupiah dan Produk Domestik Bruto Terhadap Jakarta Islamic Indeks : Jurnal Bisnis dan Managemen Eksekutif Vol. No. 1 
46 | Ash-Shidiq \& Setiawan : Analisis Pengaruh Suku Bunga SBI, Uang Beredar, Inflasi dan Nilai Tukar......

Murtianingsih. (2012). Variabel Ekonomi Makro dan Indeks Harga Saham Gabungan : Jurnal Manajemen dan Akuntansi Vol. 1 No. 3

Nastiti, Khoiru L.A \& Agus Suharsono (2012). Analisis Volatilitas Saham Perusahaan Go Public dengan Metode ARCH-GARCH : Jurnal Sains dan Seni ITS VOL 1 No. 1

Ningsih, Fatmi R. (2010). Pengaruh Inflasi dan Pertumbuhan Ekonomi Terhadap Pengangguran Di Indonesia : Skripsi Jurusan Ilmu Ekonomi dan Studi Pembangunan Fakultas Ekonomi dan Ilmu Sosial Universitas Islam Negeri Syarif Hidayatullah. Jakarta

Nofiatin, Ike. (2013). Hubungan Inflasi, Suku Bunga, Produk Domestik Bruto, Nilai Tukar, Jumlah Uang Beredar, dan Indek Harga Saham Gabungan periode 2005 - 2011 : Jurnal Aplikasi Manajemen. Vol. 11 No, 2

Novianto, Adytia. (2011). Analisis Pengaruh Nilai Tukar (Kurs) Dollar Amerika/Rupiah (Us\$/Rp), Tingkat Suku Bunga SBI, Inflasi, dan Jumlah Uang Beredar (M2) Terhadap Indek Harga Saham Gabungan (IHSG) di Bursa Efek Indonesia (BEI) Periode 2009.1 2010.6: Skripsi Fakultas Ekonomi Universitas Diponegoro. Semarang

Nugroho, Ris Yuwono Y. (2011). Dampak Fluktuasi Dinamis Makro Ekonomi, IHSG, dan Sibor Terhadap Jakarta Islamic Indeks : Jurnal Investasi Vol. 7 No. 1

Pasaribu, Rowland, B.F \& Mikail Firdaus. (2013). Analisis Pengaruh Variabel Makroekonomi Terhadap Indeks Saham Syariah Indonesia : Jurnal Ekonomi dan Bisnis Vol. 7 No. 2

Pranandari, Kinanti. (2015). Pengaruh Variabel makroekonomi dan Bursa Luar Negeri Terhadap Harga Saham di Jakarta Islamic Indek (JII) : Jurnal Imiah Jurusan Ilmu Ekonomi Fakultas Ekonomi dan Bisnis Universitas Brawijaya. Malang

Rahmi, Pebri \& Andi Irfan, (2012). Analisis Dampak Penerapan Corporate Governance Terhadap Kinerja Perusahaan Yang Termasuk Dalam Jakarta Islamic Indek di Bursa Efek Indonesia : The 1st Islamic Economic and Finance Research Forum UIN Sultan Syarif Kasim.

Rivai, H Veithzal \& Andi Buchori. (2013). Islamic Economics: Ekonomi Syariah Bukan Opsi, Tetapi Solusi : PT Bumi Aksara. Jakarta

Rivai, Veithzal \& Arviyan Arifin. (2010). Islamic Banking Sebuah Teori, Konsep, dan Aplikasi : PT Bumi Aksara. Jakarta

Rodoni, Ahmad \& Abdul Hamid. (2008). Lembaga Keuangan Syariah : Penerbit Zikrul Hakim. Jakarta

Rosadi, Dedi. (2012). Ekonometrika Analisis Runtun Waktu Terapan dengan Eviews : Edisi I. Penerbit CV Andi Offset. Yogyakarta

Roziq, Ahmad \& Mufti Mubarok. (2012). Buku Cerdas Investasi \& Transaksi Syariah : Dinar Media. Jakarta

Samsul, Mohamad. (2010). Pasar Berjangka Komoditas dan Derivatif. Penerbit : Salemba Empat. Jakarta

Satryo, Saptono B. (2006). Optimasi Portofolio Saham Syariah (Studi Kasus BEJ tahun 2002 -2004) : Jurnal Ekonomi Keuangan dan Bisnis Islami Vol 2 No 3

Soemitra, Andri. (2009). Bank Dan lembaga Keuangan Syariah. Edisi Pertama. Penerbit Kencana Prenada Media Group. Jakarta 